\title{
PENINGKATAN HASIL BELAJAR KEBERAGAMAN DI INDONESIA MELALUI PENERAPAN MODEL PEMBELAJARAN MAKE A MATCH
}

\author{
Supriyadi \\ Dinas Pendidikan Kabupaten Wonogiri \\ Email: supriyadi@gmail.com
}

\begin{abstract}
Abstrak
Penelitian ini bertujuan untuk meningkatkan hasil belajar siswa pada materi keberagaman di Indonesia melalui penerapan model pembelajaran make a match. Penelitian yang dilakukan adalah Penelitian Tindakan atau Action Research. Penelitian ini dilaksanakan di SD Negeri 1 Tawangharjo Kecamatan Giriwoyo, Wonogiri. Penelitian dilaksanakan pada Semester II Tahun Pelajaran 2019/2020. Subjek pada penelitian ini yaitu 10 siswa kelas IV SD negeri 1 Tawangharjo. Objek dalam penelitian ini adalah hasil belajar siswa tentang keberagaman Indonesia. Penelitian tindakan ini dilaksanakan dalam dua siklus yaitu siklus I dan siklus II. Hasil penelitian ini yaitu 1) Proses pembelajaran KD 3.6 dan 4.6 tentang keragaman Indonesia menggunakan model pembelajaran make a match lebih efektif, siswa menjadi lebih aktif, antusias serta berperan aktif, 2) Hasil belajar pada KD 3.6 pada siklus I diperoleh rerata 77,00 (cukup) dan siklus II diperoleh rerata 84,00 (baik), 3) Hasil belajar pada KD 4.6 pada siklus I diperoleh rerata 73,80 (cukup terampil) dan siklus II dengan rerata 86,30 (terampil).
\end{abstract}

Kata Kunci: hasil belajar, make a match, keberagaman Indonesia, proses pembelajaran.

\begin{abstract}
This study aims to improve student learning outcomes on diversity material in Indonesian through the application of the make a match learning model. The research conducted is Action Research. This research was conducted at State Elementary School 1 Tawangharjo, Wonogiri district. The research was conducted in second semester of the 2019/2020 academic year. The subjects in this research were 10 fourth grade students of State Elementary School 1 Tawangharjo. The object of this research is the result of student learning about the diversity of Indonesian. This action research was carried out in two cycles, namely first cycle and second cycle. The results of this research are 1) The learning process for basic competencies 3.6 and 4.6 about Indonesia diversity using the make a match learning model is more effective, students become nore active, enthusiastic and play an active role, 2) Learning outcomes for basic competencies 3.6 in the first cycle obtained an average of 77,00 (sufficient) and the second cycle obtained an average of 84,00 (good), 3) Learning outcomes at basic competencies 4.6 in the first cycle obtained an average of 73,80 (skilled enough) and the second cycle with an average of 86,30 (skilled).
\end{abstract}

Keywords: learning outcomes, make a match, Indonesian diversity, learning process.

\section{PENDAHULUAN}

Di Indonesia, kurikulum yang digunakan di SD yaitu kurikulum 2013 (Sakti \& Hartanto, 2020) (Sakinah \& Dewi, 2021). Kurikulum 2013 adalah kurikulum berbasis kompetensi (Dewantara \& Nurgiansah, 2021b). Di dalamnya dirumuskan secara terpadu kompetensi sikap, pengetahuan, dan keterampilan yang harus dikuasai peserta didik (Rachman et al., 2021). Selain itu dirumuskan juga proses pembelajaran dan penilaian yang diperlukan peserta didik untuk mencapai kompetensi yang diinginkan (S et al., 2021).
Pembelajaran kurikulum 2013 menggunakan pendekatan saintifik atau pendekatan berbasis proses keilmuan, pendekatan saintifik dapat menggunakan beberapa strategi seperti pembelajaran kontekstual. Kurikulum 2013 menggunakan modus pembelajaran langsung (direct instructional) dan tidak langsung (indirect nstructional) (Nurgiansah, 2021c) (Rahmelia, 2021).

Berdasarkan Peraturan Menteri Pendidikan dan Kebudayaan No. 24 Tahun 2016 yang menyatakan bahwa berdasarkan perkembangan dan kebutuhan pendidikan 
saat ini diperlukan perbaikan Kompetensi Inti dan Kompetensi Dasar yang mengakomodasikan prinsip-prinsip untuk memperkuat proses pembelajaran (Nurgiansah, 2021a) (Priyastuti, 2021). Kompetensi Inti yaitu tingkat kemampuan untuk mencapai standar kompetensi lulusan yang harus dimiliki seorang peserta didik pada setiap tingkat kelas (Pitoyo, 2021). Sedangkan Kompetensi Dasar adalah kemampuan dan materi pembelajaran minimal yang harus dicapai peserta didik untuk suatu mata pelajaran pada masingmasing satuan pendidikan yang mengacu pada Kompetensi Inti. Kompetensi Inti dalam kurikulum 2013 terdiri atas: kompetensi inti sikap spiritual, kompetensi inti sikap sosial, kompetensi inti pengetahuan, dan kompetensi inti keterampilan. Kompetensi dasar pada kurikulum 2013 berisi kemampuan dan materi pembelajaran untuk suatu mata pelajaran pada masing-masing satuan pendidikan yang mengacu pada kompetensi inti (Nurgiansah, 2021b).

Penilaian hasil belajar oleh pendidik dilakukan dalam bentuk ulangan, pengamatan, penugasan, dan/atau bentuk lain yang diperlukan. Penilaian hasil belajar oleh pendidik digunakan untuk: mengukur dan mengetahui pencapaian kompetensi peserta didik, memperbaiki proses pembelajaran; dan menyusun laporan kemajuan hasil belajar harian, tengah semester, akhir semester, akhir tahun, dan/atau kenaikan kelas.

Menurut Dimyati dan Mudjiono (2009: 200) dalam (Nurgiansah, 2020) (Ngatmiyatun, 2021) bahwa yang dimaksud dengan hasil belajar merupakan suatu proses untuk melihat sejauh mana siswa dapat menguasai pembelajaran setelah mengikuti kegiatan proses belajar mengajar, atau keberhasilan yang dicapai seorang peserta didik setelah mengikuti kegiatan pembelajaran yang ditandai dengan bentuk angka, huruf, atau simbol tertentu yang disepakati oleh pihak penyelenggara pendidikan, sehingga hasil belajar adalah kemampuan yang diperoleh individu setelah proses belajar berlangsung, yang dapat memberikan perubahan tingkah laku baik pengetahuan, pemahaman, sikap dan keterampilan siswa sehingga menjadi lebih baik dari sebelumnya. Berdasarkan Taksonomi Bloom (1956) dalam (Murniyati, 2021)(Khotidjah, 2021) (Febriani, 2019)hasil belajar dalam rangka pembelajaran meliputi 3 ranah yaitu: 1) Kognitif, 2) Afektif dan 3) Psikomotorik. Hasil belajar dapat dipengaruhi beberapa faktor yaitu faktor internal, eksternal maupun lingkungan (Nurgiansah, 2021d).

Anita Lie (Isjoni, 2011: 112) Make a Match adalah teknik dimana siswa mencari pasangan sambil belajar mengenai suatu konsep atau topik dalam suasana yang menyenangkan. Teknik ini bisa digunakan dalam semua mata pelajaran dan untuk semua tingkatan usia (Nurgiansah et al., 2020) (Nurgiansah \& Pringgowijoyo, 2020). Menurut Suprijono (2009: 94) halhal yang perlu dipersiapkan jika pembelajaran dikembangkan dengan Make a Match adalah kartu-kartu. Kartu-kartu tersebut terdiri dari kartu berisi pertanyaan-pertanyaan dan kartu-kartu yang lainnya berisi jawaban dari pertanyaan-pertanyaan tersebut. Make a Match adalah teknik mencari pasangan dimana setiap siswa menerima satu kartu. Kartu itu bisa berisi pertanyaan, bisa berisi jawaban. Selanjutnya mereka mencari pasangan yang cocok sesuai dengan kartu yang dipegang (Nurgiansah, Hendri, et al., 2021) (Nurgiansah \& Al Muchtar, 2018).

Adapun hasil belajar pada penelitian ini dititikberatkan pada KI-3 tentang pengetahuan dan KI-4 mengenai keterampilan (Nurgiansah, Pratama, et al., 2021) (Nurgiansah \& Sukmawati, 2020). Sebagai data awal pada pembelajaran materi keberagaman di Indonesia pada KD 3.2 Mengidentifikasi keberagaman sosial, ekonomi, budaya, etnis, dan agama di 
provinsi setempat sebagai identitas bangsa Indonesia serta hubungannya dengan karakteristik ruang kelas IV semester II SD Negeri 1 Tawangharjo tahun pelajaran 2019/2020 menunjukkan bahwa hasil belajar siswa sangat rendah. Hasil belajar KI-3 siswa kelas IV semester II SD Negeri 1 Tawangharjo adalah: siswa yang memerlukan bimbingan dalam menjelaskan tentang keberagaman di Indonesia sebanyak 6 siswa $(60,00 \%)$, siswa yang cukup sebanyak 1 siswa $(10,00 \%)$, siswa yang baik sebanyak 2 siswa $(20,00 \%)$, sedangkan siswa yang sangat baik sebanyak 1 siswa $(10,00 \%)$.

Rata-rata nilai hasil belajar KI-3 adalah siswa masih memerlukan bimbingan dalam menjelaskan tentang keberagaman di Indonesia. Sedangkan KKM materi menjelaskan tentang keberagaman di Indonesia yang telah ditetapkan adalah siswa memiliki kemampuan baik dalam menjelaskan tentang keberagaman di Indonesia (Dewantara, Nurgiansah, et al., 2021)(Dewantara, Hermawan, et al., 2021). Berdasarkan hasil tes tersebut, dapat disimpulkan bahwa hanya terdapat 4 siswa $(40,00 \%)$ yang tuntas. Sehingga masih terdapat 6 siswa $(60,00 \%)$ yang belum tuntas dan dapat dikatakan bahwa target daya serap siswa terhadap materi menjelaskan tentang keberagaman di Indonesia masih belum mencapai batas ketuntasan belajar yang ditetapkan yaitu 85 \% (Widodo, 2021) (Sumarni, 2021).

Penilaian hasil belajar KI-4, yang hasilnya juga masih berada dibawah target yang diharapkan. Berdasarkan hasil penilaian kondisi awal diperoleh data bahwa siswa yang kurang terampil dalam menyajikan berbagai bentuk keberagaman di Indonesia sebanyak 7 siswa $(70,00 \%)$, siswa yang memiliki kategori cukup terampil sebanyak 1 siswa $(10,00 \%)$, sedangkan siswa yang memiliki kategori terampil sebanyak 2 siswa $(20,00 \%)$. Ratarata hasil belajar KI-4 pada materi menyajikan berbagai bentuk keberagaman di Indonesia yaitu siswa memerlukan bimbingan dalam menyajikan berbagai bentuk keberagaman di Indonesia. Masih belum memenuhi kriteria yang diharapkan guru yaitu memiliki kategori terampil dalam menyajikan berbagai bentuk keberagaman di Indonesia (Sigit \& Andari, 2019) (Saptaningsih \& Astuti, 2019) (Dewantara \& Nurgiansah, 2021a)(Dewantara \& Nurgiansah, 2021c).

Permasalahan tersebut mendorong guru untuk melakukan Penelitian Tidakan Kelas (PTK). Penelitian ini berjudul "Peningkatan Hasil Belajar Keberagaman di Indonesia Melalui Penerapan Model Pembelajaran Make a Match Pada Siswa Kelas IV Semeter II SD Negeri 1 Tawangharjo Tahun Pelajaran 2019/2020". Diharapkan dengan penggunaan model pembelajaran Make a Match dapat meningkatkan hasil belajar siswa tentang keberagaman di Indonesia kelas IV semester II SD Negeri 1 Tawangharjo tahun pelajaran 2019/2020.

\section{METODE PENELITIAN}

Penelitian dilaksanakan di SD Negeri 1 Tawangharjo, Giriwoyo, Wonogiri pada siswa kelas IV semester II tahun pelajaran 2019/2020 selama 4 bulan dimulai pada bulan Januari 2020 dan diakhiri pada bulan April 2020. Subjek penelitian ini adalah siswa kelas IV SD Negeri 1 Tawangrejo Kecamatan Giriwoyo Kabupaten Wonogiri Semester 2 tahun pelajaran 2019/2020 yang jumlah siswanya ada 10 siswa dengan satu rombongan belajar. Objek penelitian adalah hasil belajar siswa tentang keberagaman di Indonesia.

Teknik pengumpulan data yang digunakan dalam penelitian ini antara lain: 1) Dokumen hasil belajar siswa materi keberagama Indonesia sebelum dilakukan tindakan, 2) Observasi yaitu mengamati proses pembelajaran, 3) Tes tertulis dan lisan, 4) Wawancara kepada siswa tentang masalah yang berkaitan dengan kondisi pembelajaran dan faktor yang 
mempengaruhinya, 5) Catatan lapangan, dan 6) Dokumentasi kegiatan. Adapun alat yang digunakan untuk mengumpulkan data berupa: 1) Dokumen hasil belajar siswa, 2) Lembar observasi, 3) Butir soal tes tertulis dan lisan, 4) Pedoman wawancara, dan 5) catatan tertulis.

Target dalam penelitian ini adalah 1) Proses Pembelajaran Siswa yang kurang baik menjadi sangat baik yang dilihat dari indicator: a) keaktifan siswa, b) keantusiasan siswa, c) kerja sama siswa dalam proses pembelajaran. 2) Hasil belajar siswa diharapkan minimal memperoleh rerata di atas KKM.

\section{HASIL PENELITIAN DAN PEMBAHASAN Hasil Penelitian Deskripsi Prasiklus}

SD Negeri 1 Tawangrejo merupakan salah satu sekolah yang terletak di Kecamatan Giriwoyo yang agak jauh dari pusat kota. Subjek penelitian adalah siswa kelas IV Semester II SD Negeri 1 Tawangrejo tahun pelajaran $2019 / 2020$ yang berjumlah 10 siswa dengan distribusi siswa laki-laki 6 siswa dan 4 siswi perempuan. Secara umum karakteristik siswa kelas IV SD Negeri 1 Tawangrejo yaitu mereka sudah berkurang sifat egosentrisnya. Daya konsentrasi anak sudah tumbuh dengan baik. Mereka dapat meluangkan lebih banyak waktu untuk tugas tugas pilihan mereka, dan seringkali mereka dengan senang hati menyelesaikannya. Tahap ini juga termasuk tumbuhnya tindakan mandiri, kerjasama dengan kelompok dan bertindak menurut cara cara yang dapat diterima lingkungan mereka. Mereka juga mulai peduli pada permainan yang jujur. Kemandirian siswa untuk belajar dan keterampilan siswa sudah cukup baik. Karena siswa kelas IV sudah mulai belajar secara mandiri.

Pembelajaran kelas IV pada KD 3.6 Mengidentifikasi berbagai bentuk keragaman suku bangsa, sosial, dan budaya di Indonesia yang terikat persatuan dan kesatuan dan KD 4.6 Menyajikan berbagai bentuk keragaman suku bangsa, sosial, dan budaya di Indonesia yang terikat persatuan dan kesatuan dilaksanakan pada hari Rabu tanggal 21 dan 28 Januari 2020 selama 7 JP. Pembelajaran dimulai dengan mengkondisikan siswa, mengucapkan salam, berdoa, presensi dan menyanyikan lagu nasional. Guru melakukan apersepsi dengan tanya jawab untuk mengecek kesiapan siswa dalam mempelajari materi keberagaman di Indonesia. Langkah berikutnya guru memberikan motivasi supaya siswa bersemangat dalam mengikuti pembelajaran. Guru menjelaskan mengenai keberagaman di Indonesia. Selama penjelasan berlangsung siswa melakukan tanya jawab dengan guru. Siswa mencatat hal-hal penting yang sudah dijelaskan oleh guru di dalam buku catatannya.

Pada pertemuan kedua guru mengadakan tes formatif materi keberagaman di Indonesia. Pembelajaran dimulai dengan mengkondisikan peserta didik, mengucapkan salam, mengadakan presensi, mengajak berdoa, dan menyanyikan lagu nasional. Kemudian guru mulai membagikan soal untuk dikerjakan siswa. Setelah pekerjaan terkumpul guru siswa menyajikan berbagai bentuk keberagaman di Indonesia. Guru mengambil nilai KI-3 dan KI-4 pada kondisi Pra Siklus, yang selanjutnya hasil dari penilaian akan dianalisis oleh guru dan kolaborator. Hasil pembelajaran prasiklus adalah sebagai berikut

Tabel 1.1

Distribusi proses pembelajaran prasiklus

\begin{tabular}{|c|c|c|c|c|c|}
\hline \multirow[b]{2}{*}{ No } & \multirow[b]{2}{*}{ Indikator } & \multicolumn{2}{|l|}{$\mathrm{Ya}$} & \multicolumn{2}{|l|}{ Tidak } \\
\hline & & $\begin{array}{l}\text { Jml } \\
\text { siswa }\end{array}$ & $\%$ & $\begin{array}{l}\text { Jml } \\
\text { siswa }\end{array}$ & $\%$ \\
\hline 1 & Aktif & 4 & 40 & 6 & 60 \\
\hline 2 & Antusias & 5 & 50 & 5 & 50 \\
\hline 3 & Kerjasama & 3 & 30 & 7 & 70 \\
\hline \multicolumn{2}{|c|}{ Rata-rata } & 4 & 40 & 6 & 60 \\
\hline \multicolumn{2}{|c|}{ Kategori } & \multicolumn{4}{|c|}{ Kurang baik } \\
\hline
\end{tabular}


Tabel 1.2

Perolehan Nilai Hasil Belajar KI-3 Prasiklus

\begin{tabular}{|c|c|c|c|c|}
\hline $\mathrm{Nc}$ & Nilai & Jumlah & $\%$ & Deskripsi \\
\hline 1 & 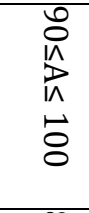 & 1 & 10 & $\begin{array}{l}\text { Siswa sangat baik } \\
\text { dalam } \\
\text { menjelaskan } \\
\text { keberagaman di } \\
\text { Indonesia }\end{array}$ \\
\hline 2 & $\begin{array}{l}\infty \\
0 \\
1 \wedge \\
\mathscr{D}_{1} \\
\infty \\
0\end{array}$ & 2 & 20 & $\begin{array}{l}\text { Siswa baik dalam } \\
\text { menjelaskan } \\
\text { keberagaman di } \\
\text { Indonesia }\end{array}$ \\
\hline 3 & 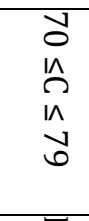 & 1 & 10 & $\begin{array}{l}\text { Siswa cukup } \\
\text { dalam } \\
\text { menjelaskan } \\
\text { keberagaman di } \\
\text { Indonesia }\end{array}$ \\
\hline 4 & $\begin{array}{l}\vec{v} \\
\wedge \\
0\end{array}$ & 6 & 60 & $\begin{array}{l}\text { Siswa } \\
\text { memerlukan } \\
\text { bimbingan } \\
\text { menjelaskan } \\
\text { keberagaman di } \\
\text { Indonesia }\end{array}$ \\
\hline \multicolumn{2}{|c|}{ Jumlah } & 10 & 100 & \multirow{3}{*}{$\begin{array}{l}\text { Rata-rata siswa } \\
\text { memerlukan } \\
\text { bimbingan dalam } \\
\text { menjelaskan } \\
\text { keberagaman di } \\
\text { Indonesia }\end{array}$} \\
\hline \multicolumn{2}{|c|}{\begin{tabular}{|l|} 
Siswa \\
Tuntas
\end{tabular}} & 4 & 40 & \\
\hline \multicolumn{2}{|c|}{$\begin{array}{l}\text { Siswa } \\
\text { Belum } \\
\text { Tuntas }\end{array}$} & 6 & 60 & \\
\hline
\end{tabular}

Tabel 1.3

Perolehan Nilai Hasil Belajar KI-4 prasiklus

\begin{tabular}{|c|c|c|c|c|}
\hline No & Nilai & Jumlah & $\%$ & Deskripsi \\
\hline 1 & 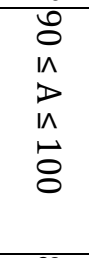 & 0 & 0 & $\begin{array}{l}\text { Siswa sangat } \\
\text { terampil dalam } \\
\text { menyajikan } \\
\text { berbagai bentuk } \\
\text { keberagaman di } \\
\text { Indonesia }\end{array}$ \\
\hline 2 & $\begin{array}{l}\infty \\
0 \\
1 \wedge \\
\infty \\
11 \\
\infty \\
\infty \\
0\end{array}$ & 1 & 10 & $\begin{array}{l}\text { Siswa terampil } \\
\text { dalam } \\
\text { menyajikan } \\
\text { berbagai bentuk } \\
\text { keberagaman di } \\
\text { Indonesia }\end{array}$ \\
\hline 3 & 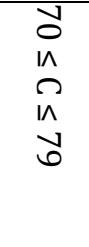 & 2 & 20 & $\begin{array}{l}\text { Siswa cukup } \\
\text { terampil dalam } \\
\text { menyajikan } \\
\text { berbagai bentuk } \\
\text { keberagaman di } \\
\text { Indonesia }\end{array}$ \\
\hline
\end{tabular}

\begin{tabular}{|c|c|c|c|c|}
\hline 4 & $\begin{array}{l}\nabla \\
\wedge \\
\text { ov }\end{array}$ & 7 & 70 & $\begin{array}{l}\text { Siswa kurang } \\
\text { terampil dalam } \\
\text { menyajikan } \\
\text { berbagai bentuk } \\
\text { keberagaman di } \\
\text { Indonesia }\end{array}$ \\
\hline Jumlah & & 10 & 100 & \multirow{3}{*}{$\begin{array}{l}\text { Rata-rata siswa } \\
\text { kurang terampil } \\
\text { dalam } \\
\text { menyajikan } \\
\text { berbagai bentuk } \\
\text { keberagaman di } \\
\text { Indonesia }\end{array}$} \\
\hline $\begin{array}{l}\text { Siswa } \\
\text { Tuntas }\end{array}$ & & 3 & 30 & \\
\hline $\begin{array}{l}\text { Siswa } \\
\text { Belum } \\
\text { Tuntas }\end{array}$ & & 7 & 70 & \\
\hline
\end{tabular}

\section{Pembahasan \\ Deskripsi Siklus I}

Siklus I dilakukan dalam 2 pertemuan. Pertemuan 1 dilaksanakan pembelajaran materi keberagaman Indonesia KD 3.6 dan 4.6. Guru menyampaikan materi pembelajaran dengan menggunakan model make a match dimana siswa diberikan beberapa kartu bergambar dan diminta untuk memeasangkan kartu tersebut pada nama pulau yang sesuai.

Pertemuan 2, diawal pembelajaran siswa diminta untuk membaca buku yang disediakan dan selanjutnya dilakukan tes tertulis.

Indikator yang mengalami peningkatan pada siklus I dapat dilihat pada tabel berikut

Tabel 1.4

Distribusi Proses Pembelajaran Siklus I

\begin{tabular}{|l|l|l|l|l|l|}
\hline \multirow{2}{*}{ No } & \multirow{2}{*}{ Indikator } & \multicolumn{2}{|l|}{ Ya } & \multicolumn{2}{l|}{ Tidak } \\
\cline { 3 - 6 } & & $\begin{array}{l}\text { Jml } \\
\text { siswa }\end{array}$ & $\%$ & $\begin{array}{l}\text { Jml } \\
\text { siswa }\end{array}$ & $\%$ \\
\hline 1 & Aktif & 7 & 70 & 3 & 30 \\
\hline 2 & Antusias & 8 & 80 & 2 & 20 \\
\hline 3 & Kerjasama & 6 & 60 & 4 & 40 \\
\hline \multicolumn{7}{|l|}{ Rata-rata } & 7 & 70 & 3 & 30 \\
\hline \multicolumn{2}{|l|}{ Kategori } &
\end{tabular}

Tabel 1.5

Perolehan Nilai Hasil Belajar KI-3 dan KI-4 Siklus I

\begin{tabular}{|l|l|l|l|l|l|}
\hline \multirow{2}{*}{ No } & \multirow{2}{*}{ Nilai } & \multicolumn{2}{|l|}{ KI-3 } & \multicolumn{2}{l|}{ KI-4 } \\
\cline { 3 - 5 } & & Jumlah & $\%$ & Jumlah & $\%$ \\
\hline
\end{tabular}




\begin{tabular}{|l|l|l|l|l|l|}
\hline 1 & $\begin{array}{l}90 \leq \mathrm{A} \\
\leq 100\end{array}$ & 4 & 40 & 1 & 10 \\
\hline 2 & $\begin{array}{l}80 \leq \\
\mathrm{B} \leq 89\end{array}$ & 1 & 10 & 2 & 20 \\
\hline 3 & $\begin{array}{l}70 \leq \mathrm{C} \\
\leq 79\end{array}$ & 2 & 20 & 3 & 30 \\
\hline 4 & $\begin{array}{l}\mathrm{D}< \\
70\end{array}$ & 3 & 30 & 4 & 40 \\
\hline Jumlah & 10 & 100 & 10 & 100 \\
\hline $\begin{array}{l}\text { Siswa } \\
\text { Tuntas }\end{array}$ & 7 & 70 & 6 & 60 \\
\hline $\begin{array}{l}\text { Siswa } \\
\text { Belum } \\
\text { Tuntas }\end{array}$ & 3 & 30 & 4 & 40 \\
\hline
\end{tabular}

\section{Refleksi}

Hasil refleksi bahwa di dalam proses pembelajaran siswa sudah mulai tertarik dengan model pembelajaran Make a Match yang dilakukan guru. Berdasarkan hasil refleksi sudah terdapat peningkatan keaktifan , antusiasme, dan kerja sama siswa dalam proses pembelajaran. Ratarata proses pembelajaran berada dalam kategori baik, meningkat dibandingkan kondisi prasiklus.

\section{Deskripsi Siklus II}

Siklus II dilakukan dalam 2 pertemuan. Pertemuan 1 dilaksanakan pembelajaran materi keberagaman Indonesia KD 3.6 dan 4.6. Guru menyampaikan materi pembelajaran dengan menggunakan model make a match dimana siswa diberikan beberapa kartu bergambar dan diminta untuk memeasangkan kartu tersebut pada nama pulau yang sesuai.

Pertemuan 2, diawal pembelajaran siswa diminta untuk membaca buku yang disediakan dan selanjutnya dilakukan tes tertulis. Indikator yang mengalami peningkatan pada siklus II dapat dilihat pada tabel berikut
Tabel 1.6

Distribusi Proses Pembelajaran Siklus I

\begin{tabular}{|c|c|c|c|c|c|}
\hline \multirow[b]{2}{*}{ No } & \multirow[b]{2}{*}{ Indikator } & \multicolumn{2}{|l|}{ Ya } & \multicolumn{2}{|l|}{ Tidak } \\
\hline & & $\begin{array}{l}\text { Jml } \\
\text { siswa }\end{array}$ & $\%$ & $\begin{array}{l}\text { Jml } \\
\text { siswa }\end{array}$ & $\%$ \\
\hline 1 & Aktif & 10 & 100 & 0 & 0 \\
\hline 2 & Antusias & 10 & 100 & 0 & 0 \\
\hline 3 & Kerjasama & 10 & 100 & 0 & 0 \\
\hline \multicolumn{2}{|c|}{ Rata-rata } & 10 & 100 & 0 & 0 \\
\hline \multicolumn{2}{|c|}{ Kategori } & \multicolumn{4}{|c|}{ Sangat Baik } \\
\hline
\end{tabular}

Tabel 1.7

Perolehan Nilai Hasil Belajar KI-3 dan KI-4 Siklus II

\begin{tabular}{|c|c|c|c|c|c|}
\hline \multirow{2}{*}{ No } & \multirow{2}{*}{ Nilai } & \multicolumn{2}{|l|}{ KI-3 } & \multicolumn{2}{|l|}{$\mathrm{KI}-4$} \\
\hline & & Jumlah & $\%$ & Jumlah & $\%$ \\
\hline 1 & $\begin{array}{l}90 \leq \mathrm{A} \\
\leq 100\end{array}$ & 5 & 50 & 2 & 20 \\
\hline 2 & $\begin{array}{l}80 \leq \\
B \leq 89\end{array}$ & 1 & 10 & 5 & 50 \\
\hline 3 & $\begin{array}{l}70 \leq C \\
\leq 79\end{array}$ & 4 & 40 & 3 & 30 \\
\hline 4 & $\begin{array}{l}\mathrm{D}< \\
70\end{array}$ & 0 & 0 & 0 & 0 \\
\hline \multicolumn{2}{|c|}{ Jumlah } & 10 & 100 & 10 & 100 \\
\hline \multicolumn{2}{|c|}{$\begin{array}{l}\text { Siswa } \\
\text { Tuntas }\end{array}$} & 10 & 100 & 10 & 100 \\
\hline \multicolumn{2}{|c|}{$\begin{array}{l}\text { Siswa } \\
\text { Belum } \\
\text { Tuntas }\end{array}$} & 0 & 0 & 0 & 0 \\
\hline
\end{tabular}

\section{Refleksi}

Hasil refleksi menunjukkan bahwa di dalam proses pembelajaran sangat tertarik dengan model pembelajaran make a match yang diberikan guru. Berdasarkan hasil refleksi sudah terdapat peningkatan keaktifan, antusiasme, dan kerja sama siswa dalam proses pembelajaran. Rata-rata proses pembelajaran berada dalam kategori sangat baik, meningkat dibandingkan kondisi Siklus I

\section{Pembahasan}

Proses pembelajaran Pra Siklus, Siklus I dan Siklus II diperoleh hasil bahwa tingkat keaktifan siswa pada kondisi pra siklus sebesar 40,00 \%, kemudian meningkat menjadi 70,00 \% pada Siklus I, dan terakhir pada kondisi Siklus II menjadi 
$100 \%$. Tingkat antusiasme siswa kondisi pra siklus sebesar 50,00\%, kemudian meningkat menjadi $80,00 \%$ pada Siklus I, dan terakhir pada kondisi Siklus II menjadi $100 \%$. Tingkat kerja sama siswa dalam proses pembelajaran kondisi pra siklus sebesar 30,00 \%, kemudian meningkat menjadi $60,00 \%$ pada Siklus I, dan terakhir pada kondisi Siklus II menjadi $100 \%$. Sudah memenuhi Indikator kinerja yang sudah ditetapkan yaitu dalam kategori minimal sangat baik.

Pada kondisi Pra Siklus nilai hasil belajar KD 3.6 berada dalam kategori ratarata siswa masih memerlukan bimbingan dalam memahami keberagaman di Indonesia. Selain nilai hasil belajar pada kondisi pra siklus target ketuntasan klasikal juga masih rendah, yaitu 40,00\%. Masih jauh berada dibawah Indikator Kinerja yang ditetapkan sebesar 80,00\%. Nilai hasil belajar pada kondisi Siklus I target ketuntasan klasikal mengalami peningkatan menjadi 70,00\%, namun masih berada dibawah Indikator Kinerja yang ditetapkan yaitu minimal 80,00\%. Pada kondisi Siklus II nilai hasil belajar Target ketuntasan klasikal mengalami peningkatan menjadi $100 \%$. Sudah melampai Indikator Kinerja yang ditetapkan yaitu minimal $80,00 \%$.

Pada Pra Siklus nilai hasil belajar KI4 pada KD 4.6 target ketuntasan klasikal juga masih rendah yaitu 30,00\%. Masih dibawah Indikator Kinerja yang ditetapkan sebesar 80,00\%. Pada Siklus I nilai hasil belajar KI-4 pada KD 4.6 target ketuntasan klasikal mengalami peningkatan menjadi $60,00 \%$. Masih berada dibawah Indikator Kinerja yang ditetapkan yaitu minimal 80,00\%. Pada Siklus II nilai hasil belajar KI4 pada KD 4.6 target ketuntasan klasikal mengalami peningkatan menjadi $100 \%$ dan sudah melampaui Indikator Kinerja yang ditetapkan yaitu minimal 80,00\%.

\section{KESIMPULAN}

Kesimpulan dari hasil penelitian ini
yaitu melalui penerapan model
pembelajaran Make a Match pada siswa
Kelas IV Semester II SD Negeri 1
Tawangharjo Kecamatan Giriwoyo
Kabupaten Wonogiri Tahun Pelajaran
$2019 / 2020$ lebih efektif dan meningkat
serta berjalan lancar sesuai dengan RPP
yang telah disusun. Selain itu hasil belajar
siswa juga meningkat, pada KD 3.6 rata-rata
hasil belajar kondisi pra siklus adalah 62,00 ,
pada siklus I rata-ratanya adalah 77,00 dan
pada siklus II rata-ratanya 84,00 dengan
kategori baik. Pada KD 4.6, nilai rata-rata
hasil belajar kondisi pra siklus adalah 61,30,
siklus I diperoleh 73,80 dan pada siklus II
adalah 86,30 dengan kategori siswa
terampil.

\section{DAFTAR PUSTAKA}

A. Juntika, Nurihsan, Yusuf, Syamsu, 2010, Landasan Bimbingan dan Konseling, Bandung: PT. Remaja Rosdakarya

Agus suprijono. 2010. Cooperative Learning. Yogyakarta. Pustaka Media.

Ana Esti Ikasari. 2013. Penerapan Model Make a Match dengan Media Flashcard dalam Pembelajaran IPA untuk Meningkatkan Aktivitas Siswa Kelas VB SD Islam Al Madina. PGSD

Ani Nurfitriyani. 2016. Meningkatkan Hasil Belajar Siswa Pada Materi Keragaman Suku Bangsa dan Budaya di Indonesia Melaui Penggunaan Model Cooperative Learning Tipe STAD

Anita Lie. 2011. Cooperative Learning Mempraktikkan Cooperative Learning di RuangRuangKelas. (Jakarta: Grasindo)

Arikunto, Suharsimi. 2002. Metodologi Penelitian. Penerbit PT. Rineka Cipta. Jakarta Dalyono. M. 2007. Psikologi Pendidikan. Jakarta: Rineka Cipta. 
Danim, Sudarwan. 2013. Inovasi Pendidikan dalam Upaya Peningkatan Profesionalisme Tenaga Kependidikan. Bandung: CV Pustaka Setia.

Dewantara, J. A., Hermawan, Y., Yunus, D., Prasetiyo, W. H., Efriani, Arifiyanti, F., \& Nurgiansah, T. H. (2021). Anti-Corruption Education as an Effort to Form Students With Character Humanist and Law-Compliant. Jurnal Civics: Media Kajian Kewarganegaraan, 18(1), 70-81. Dewantara, J. A., \& Nurgiansah, T. H. (2021a). Building Tolerance Attitudes Of PPKN Students Through Multicultural Education Courses. Jurnal Etika Demokrasi, 6(1), 103-115.

Dewantara, J. A., \& Nurgiansah, T. H. (2021b). Peningkatan Keaktifan Belajar Melalui Penerapan Model Picture And Picture Dalam Pembelajaran PPKn di Sekolah Dasar. Jurnal Publikasi Pendidikan, 11(3), 234-241.

Dewantara, J. A., \& Nurgiansah, T. H. (2021c). Strengthening Pancasila Values During the Covid19 Pandemic. Edukatif: Jurnal Ilmu Pendidikan, 3(4), 2411-2417.

Dewantara, J. A., Nurgiansah, T. H., \& Rachman, F. (2021). Mengatasi Pelanggaran Hak Asasi Manusia dengan Model Sekolah Ramah HAM (SR-HAM). Edukatif: Jurnal Ilmu Pendidikan, 3(2), 261-269.

Dimyati dan Mudjiono. 2009. Belajar dan Pembelajaran. Jakarta : Rineka Cipta.

Febriani, N. W. (2019). Pendekatan Saintifik Sebagai Konsep Dasar Pembelajaran Siswa di Sanggar Anak Alam (SALAM) Nitiprayan Yogyakarta. Jurnal Kewarganegaraan, 3(1), 3540.

Khotidjah, D. (2021). Peningkatan Penggunaan Past Tense Dalam Text Recount Melalui Model STAD pada Siswa. Jurnal Kewarganegaraan, 5(1), 86-91.

Hamalik, Oemar, 2007. Manajemen Pengembangan Kurikulum, Bandung: PT. Remaja Rosda Karya

Hosnan, M. 2014. Pendekatan Saintifik dan Kontekstual dalam Pembelajaran Abad 21: Ghalia Indonesia

Huda, Miftahul. 2012. Cooperative Learning. Yogyakarta: Pustaka Belajar.

Kemendikbud. 2014. Permendikbud Nomor 103 Tahun 2014 Tentang Pembelajaran Pada Pendidikan Dasar dan Pendidikan Menengah Jakarta: Kementerian Pendidikan dan Kebudayaan RI.

Kemendikbud. 2016. Permendikbud Nomor 24 Tahun 2016 Tentang Kompetensi Inti dan Kompetensi Dasar Pelajaran Pada Kurikulum 2013 pada Pendidikan Dasar dan Menengah Jakarta: Kemendikbud

Kurinasih, Imas. 2014. Sukses Mengimplementasikan Kurikulum 2013. Kata Pena

Muhibbin Syah. 2011. Psikologi Belajar. Jakarta: Raja Brapindo Persada

Nana Sudjana. 2009. Penilaian Hasil Proses Belajar Mengajar. Bandung: PT Remaja Rosdakarya.

Murniyati, M. (2021). Peningkatan Kemampuan Menyusun Rpp Pembelajaran Kooperatif Melalui Program Supervisi Akademik Bagi Guru Kelas. Jurnal Kewarganegaraan, 5(1), 7176. https://journal.upy.ac.id/index.php/pkn/article/view/1330

Ngatmiyatun, B. (2021). Peningkatan Kemampuan Penggunaan Microsoft Office 365 Melalui Pelatihan Dan Simulasi Pada Guru Sekolah Dasar. Jurnal Kewarganegaraan, 5(1), 77-85.

Nurgiansah, T. H. (2020). Pelatihan Penulisan Artikel Ilmiah Bagi Mahasiswa PPKn Universitas PGRI Yogyakarta. JNPM: Jurnal Nasional Pengabdian Masyarakat, 1(1), 16-23.

Nurgiansah, T. H. (2021a). Partisipasi Politik Masyarakat Sleman di Masa Pandemi Covid-19 dalam Konteks Pendidikan Kewarganegaraan. Jurnal Civic Hukum, 6(1), 1-9.

Nurgiansah, T. H. (2021b). Pemanfaatan E-Learning Dalam Pembelajaran Pendidikan Kewarganegaraan. JINTECH: Journal of Information Technology, 2(2), 138-146.

Nurgiansah, T. H. (2021c). Petuah Pendidikan Kewarganegaraan Dalam Kontestasi Politik. AoEJ: Academy of Education Journal, 12(1), 39-47. 
Nurgiansah, T. H. (2021d). The Role of Citizenship Education in Building Bantul Community Political Participation in The Pandemic Covid 19. Prosiding Seminar Nasional Pendidikan Dan Kewirausahaan, 4(1), 1-4.

Nurgiansah, T. H., \& Al Muchtar, S. (2018). Development of Student Awareness through Student Learning Model Jurisprudential in Citizenship Education. ATLANTIS PRESS, 251(Acec), 670-674. https://doi.org/10.2991/acec-18.2018.150

Nurgiansah, T. H., Dewantara, J. A., \& Rachman, F. (2020). The Implementation of Character Education in the Civics Education Syllabus at SMA Negeri 1 Sleman. Jurnal Etika Demokrasi, 5(2), 110-121.

Nurgiansah, T. H., Hendri, \& Khoerudin, C. M. (2021). Role Playing Dalam Pembelajaran Pendidikan Pancasila dan Kewarganegaraan. Jurnal Kewarganegaraan, 18(1), 56-64. https://doi.org/10.24114/jk.v18i1.22597

Nurgiansah, T. H., Pratama, F. F., \& Iman, A. S. (2021). Penelitian Tindakan Kelas Dalam Pendidikan Kewarganegaraan. Jurnal Pendidikan Pancasila Dan Kewarganegaraan, 2(1), 10-23.

Nurgiansah, T. H., \& Pringgowijoyo, Y. (2020). Pelatihan Penggunaan Model Pembelajaran Jurisprudensial Pada Guru Di KB TK Surya Marta Yogyakarta. KUAT: Keuangan Umum Dan Akuntansi Terapan. PKNSTAN, 2(1).

Nurgiansah, T. H., \& Sukmawati. (2020). Tantangan Guru Pendidikan Kewarganegaraan Di Masa Adaptasi Kebiasaan Baru. Jurpis: Jurnal Pendidikan Ilmu Sosial, 17(2), 139-149.

Pitoyo, S. J. (2021). Upaya Meningkatkan Kompetensi Penyusunan RPP Berkarakter Melalui Praktik Unjuk Kerja. Jurnal Kewarganegaraan, 5(1), 120-126.

Priyastuti, K. E. (2021). Upaya Meningkatkan Hasil Belajar Siswa Menggunakan Metode Snowball Throwing. Jurnal Kewarganegaraan, 5(1), 92-100.

Purwanto. 2008. Metodologi Penelitian Kuantitatif. Yogyakarta: Pustaka Pelajar

Ramadhan, Tarmizi. 2015. Pembelajaran Kooperatif "Make A Match". http://tarmizi.wordpress.com/205/12/03/pembelajaran-kooperatif-make-amatch/.

Diambil pada tanggal 22 Maret 2020

Rachman, F., Nurgiansah, T. H., \& Kabatiah, M. (2021). Profilisasi Pendidikan Kewarganegaraan dalam Kurikulum Pendidikan Indonesia. Edukatif: Jurnal Ilmu Pendidikan, 3(5), 29702984.

Rahmelia, S. (2021). Pemaknaan Mahasiswa Terhadap Narasi Konflik Beragama. Jurnal Kewarganegaraan, 5(1), 45-54.

S, H. C., Alamsyah, M., Izzrufi, M. I., L, S. R., \& Saepudin, E. (2021). Persepsi Mahasiswa/i Terhadap Wacana Amandemen UUD NRI 1945 (Survei terhadap Mahasiswa STEI ITB Angkatan 2018). Jurnal Kewarganegaraan, 5(1), 13-20.

Shafira Dwintha Aulia. 2018. Penerapan Model Make a Match Berbasis Saintifik Untuk Meningkatkan Hasil Belajar Tematik Siswa Kelas I SD Negeri Salatiga 05 Tahun Pelajaran 2017/2018. PGSD. Universitas Satya Wacana. Salatiga

Sakinah, R. N., \& Dewi, D. A. (2021). Implementasi Nilai-Nilai Pancasila Sebagai Karakter Dasar Para Generasi Muda Dalam Menghadapi Era Revolusi Industrial 4 . 0. Jurnal Kewarganegaraan, 5(1), 152-167.

Sakti, R. O., \& Hartanto, S. (2020). Meningkatkan Prestasi Belajar Ppkn Dengan Menggunakan Model Brain Based Learning. Jurnal Kewarganegaraan, 4(1), 38-44. https://journal.upy.ac.id/index.php/pkn/article/view/1171

Saptaningsih, R. I., \& Astuti, W. (2019). Peranan Yayasan Annisa Swasti (Yasanti) Dalam Upaya Perlindungan Dan Pemberdayaan Buruh Gendong Perempuan Di Pasar Beringharjo Yogyakarta. Jurnal Kewarganegaraan, 3(1), 46-55. https://doi.org/10.31316/jk.v3i1.512 
Sigit, H., \& Andari, R. (2019). Penyelesaian Sengketa Tanah Melalui Mediasi Di Kantor Pertanahan Kabupaten Kulon Progo. Jurnal Kewarganegaraan, 3(1), 41-45. https://doi.org/10.31316/jk.v3i1.510

Sumarni. (2021). Model Pembelajaran Make a Match Untuk Meningkatkan HAsil Belajar Penyesuaian Diri dengan Lingkungan pada Siswa. Jurnal Kewarganegaraan, 5(1), 39-44.

Widodo, M. (2021). Upaya Meningkatkan Kompetensi Guru dalam Penguasaan Kurikulum 2013 Melalui In Service Learning. Jurnal Kewarganegaraan, 5(1), 113-119.

Wirawan Andianto Abdullah. 2015. Penerapan Model Pembelajaran Kooperatif Tipe Make A Match dalam Meningkatkan Minat dan Hasil Belajar Matematika Siswa Kelas III SD Negeri 3 Palar Klaten 